\title{
In silico studies, chemical composition, antibacterial activity and in vitro antigen- induced phagocytosis of Stryphnodendron adstringens (Mart.) Coville
}

\author{
Estudos in silico, composição química, atividade antibacteriana e fagocitose in vitro induzida por \\ antígeno de Stryphnodendron adstringens (Mart.) Coville
}

Estudios in silico, composición química, actividad antibacteriana y fagocitosis in vitro inducida por el antígeno de Stryphnodendron astringens (Mart.) Coville

Paulo Inácio Bueno

ORCID: https://orcid.org/0000-0003-4676-739X University Regional Center of Espírito Santo do Pinhal, Brazil E-mail: pib.bueno@gmail.com

Daisy Machado

ORCID: https://orcid.org/0000-0002-6435-6159 Universidade São Francisco, Brazil State University of Campinas, Brazil E-mail: daisy.machado@gmail.com

Marcelo Lancellotti

ORCID: https://orcid.org/0000-0002-4257-1034 State University of Campinas, Brazil E-mail:mlancell@unicamp.br Carolina Passarelli Gonçalves

ORCID: https://orcid.org/0000-0002-4759-100X

Anhanguera University of São Paulo, Brazil E-mail: carol_passarelli@ hotmail.com

Maria Cristina Marcucci

ORCID: https://orcid.org/0000-0002-8065-5618 Paulista State University "Júlio de Mesquita Filho", Brazil E-mail: cris.marcucci@yahoo.com.br

Alexandra Christine Helena Frankland Sawaya

ORCID: https://orcid.org/0000-0001-7524-6628 State University of Campinas, Brazil E-mail: achfsawa@unicamp.br

Adriana de Melo

ORCID: https://orcid.org/0000-0002-3925-0707 University Regional Center of Espírito Santo do Pinhal, Brazil State University of Campinas, Brazil E-mail: koymelo@yahoo.com.br

\begin{abstract}
We investigate the chemical composition of aqueous and hydroethanolic extracts of Stryphnodendron adstringens by evaluating the total polyphenolic and tannin contents, antioxidant activity as well as marker compounds by UHPLCMS. Through the in silico approach the molecular and pharmacokinetic parameters were predicted for the two major substances found in the extract, the pyrogallol (1) and chlorogenic acid (2). The antibacterial activity was verified by determining the MIC of the extracts on different bacterial strains. The inhibition zone diameter (ZD) of three different extracts of $S$. adstringens was studied, those with $Z \mathrm{D}>10 \mathrm{~mm}$ proceeded to the determination of the MICs. The most active antimicrobial sample was $S$. adstringens ST3. The extracts of $S$. adstringens analyzed herein demonstrated not only high content of polyphenols and total tannins, but also antioxidant activity and activity against important bacterial pathogens like Streptococcus pneumoniae, Neisseria gonorrhoeae as well as against multiresistant bacteria such as MRSA (Methicillin-resistant Staphylococcus aureus) and Pseudomonas aeruginosa. The effects of S. adstringens extract on the phagocytosis and intracellular killing of Candida albicans and Candida. kefyr from two normal individuals were studied. We propose that the effect of $S$. adstringens on the neutrophils may be related to a possible mechanism for regulation functions in these cells.
\end{abstract}

Keywords: Stryphnodendron adstringens; Antimicrobial activity; UHPLC-MS; Lytic function; Phagocytosis. 


\begin{abstract}
Resumo
Investigamos a composição química dos extratos aquosos e hidroetanólicos de Stryphnodendron adstringens, avaliando o conteúdo total de polifenóis e taninos, a atividade antioxidante, bem como os compostos marcadores por UHPLC-MS. Através da abordagem in silico, os parâmetros moleculares e farmacocinéticos foram previstos para as duas principais substâncias encontradas no extrato, o pirogalol (1) e o ácido clorogênico (2). A atividade antibacteriana foi verificada através da determinação da CIM dos extratos em diferentes cepas bacterianas. Foi avaliado o diâmetro da zona de inibição (ZD) de três extratos diferentes de $S$. adstringens, aqueles com ZD>10mm procederam à determinação do MIC. A amostra antimicrobiana mais ativa foi $S$. adstringens ST3. Os extratos de $S$. adstringens aqui analisados demonstraram não apenas alto conteúdo de polifenóis e taninos totais, mas também atividade antioxidante e atividade contra importantes patógenos bacterianos como Streptococcus pneumoniae, Neisseria gonorreia, bem como contra bactérias multirresistentes como MRSA (Staphylococcus aureus resistente à meticilina) e Pseudomonas aeruginosa. Foram estudados os efeitos do extrato de $S$. adstringens sobre a fagocitose e morte intracelular de Candida albicans e Candida kefyr de dois indivíduos normais. Propomos que o efeito do $S$. adstringens sobre os neutrófilos pode estar relacionado a um possível mecanismo de regulação das funções destas células.
\end{abstract}

Palavras-chave: Stryphnodendron adstringens; Atividade antimicrobiana; UHPLC-MS; Função lítica; Fagocitose.

\begin{abstract}
Resumen
Investigamos la composición química de los extractos acuoso e hidroetanólico de Stryphnodendron adstringens evaluando el contenido total de polifenoles y taninos, la actividad antioxidante y los compuestos marcadores a través de UHPLC-MS. Mediante el enfoque in silico se predijeron los parámetros moleculares y farmacocinéticos de las dos sustancias principales encontradas en el extracto, el pirogalol (1) y el ácido clorogénico (2). La actividad antibacteriana se verificó determinando la CIM de los extractos en diferentes cepas bacterianas. Se estudió el diámetro de la zona de inhibición (ZD) de tres extractos diferentes de S. adstringens, aquellos con ZD>10mm procedieron a la determinación de las CIM. La muestra antimicrobiana más activa fue $S$. adstringens ST3. Los extractos de $S$. adstringens aquí analizados demostraron no sólo un alto contenido de polifenoles y taninos totales, sino también actividad antioxidante y actividad contra importantes patógenos bacterianos como Streptococcus pneumoniae, Neisseria gonorrhoeae, así como contra bacterias multirresistentes como MRSA (Staphylococcus aureus resistente a la meticilina) y Pseudomonas aeruginosa. Se estudiaron los efectos del extracto de $S$. adstringens en la fagocitosis y la eliminación intracelular de Candida albicans y Candida kefyr de dos individuos normales. Proponemos que el efecto de $S$. adstringens sobre los neutrófilos puede estar relacionado con un posible mecanismo de regulación de funciones en estas células.
\end{abstract}

Palabras clave: Stryphnodendron adstringens; Actividad antimicrobiana; UHPLC-MS; Función lítica; Fagocitosis.

\title{
1. Introduction
}

Plants are important sources of biologically active natural products, many of which constitute models for the synthesis of a large number of drugs. In recent decades, research related to herbal remedies that can offer an alternative treatment of bacterial control has intensified (Pupo, et al., 2007). The study of these agents is essential as they are global, less toxic, but highly effective against bacterial resistance and able to combat new pathogens (Ostrosky, et al., 2008). With a chemical structure that differs from that of antibiotics derived from microorganisms, plant antibiotics may govern the intermediary metabolism of pathogens by activating or blocking reactions and enzyme synthesis or even changing the structure of membranes (Ishida, et al., 2009). Also, herbal medicines have a low cost and can be used in conjunction with allopathic medicine, and their use is encouraged by the World Health Organization (Silveira, et al., 2008). The Brazilian Cerrado, is a region with vegetation similar to savannah, ranges from the Amazon, along the Central Plateau, and reaches the Southeast of Brazil (Minas Gerais and São Paulo) (Felfili, et al., 2002). In order to investigate the potential of plant species from the Brazilian Cerrado and encourage the use of these renewable resources, the present study aimed to investigate the antimicrobial action of Stryphnodendron adstringens (Mart.) Coville (S.adstringens), a medicinal plant rich in tannins. Phytochemical analysis of the ethanolic extract of the bark of S. adstringens has detected the presence of tannins, flavonoids, alkaloids and two substances, pyrogallol 1 and chlorogenic acid 2, which have been previously studied through in silico approaches, demonstrating a high potential for antibacterial targets (Mellini, et al., 2019). Moreover, several specimens of this genus are used in folk medicine for the healing of wounds, leucorrhoea, antibacterial activity, gynecological problems, as anti- 
ulcerogenic, antihypertensive and as an anti-inflammatory agent which can be explained by a high concentration of tannins in its bark (Flores, et al., 2013). Therefore, the antibacterial activity of the alcoholic extracts of S. adstringens bark was investigated herein. However, the quality of the final product can only be guaranteed by having quality parameters for raw materials and adequate process control during the manufacture of the products. Thus, the quality of a herbal product starts with the evaluation of the botanical identity of the material, the evaluation of its purity, and characterization of the chemical constituents of the species, especially those involved in the therapeutic activity (Vendruscolo, et al., 2005).

\section{Methodology}

\subsection{Plant material}

Three samples of S. adstringens bark were acquired in natural product stores in Campinas (province of SP, Brazil). The three samples were purchased from different manufacturers. These plant products follow the sanitary conditions determined by the Brazilian Health Ministry and we used samples that had a quality certificate.

\subsection{Extract preparation}

To obtain the extracts, ground bark was extracted in a mixture of ethanol: water (9:1, V/V) (Nakamura, et al., 2006). The material was filtered and dried under reduced pressure, at a temperature of $45^{\circ} \mathrm{C}$ for evaporation of the solvent, obtaining a viscous crude extract, which was then taken to the oven at $60^{\circ} \mathrm{C}$ to finish the drying process, obtaining the dry hydroalcoholic extract of S. adstringens (EHBB) (Scheme 1).

Scheme 1: Fluxogram of extraction procedure

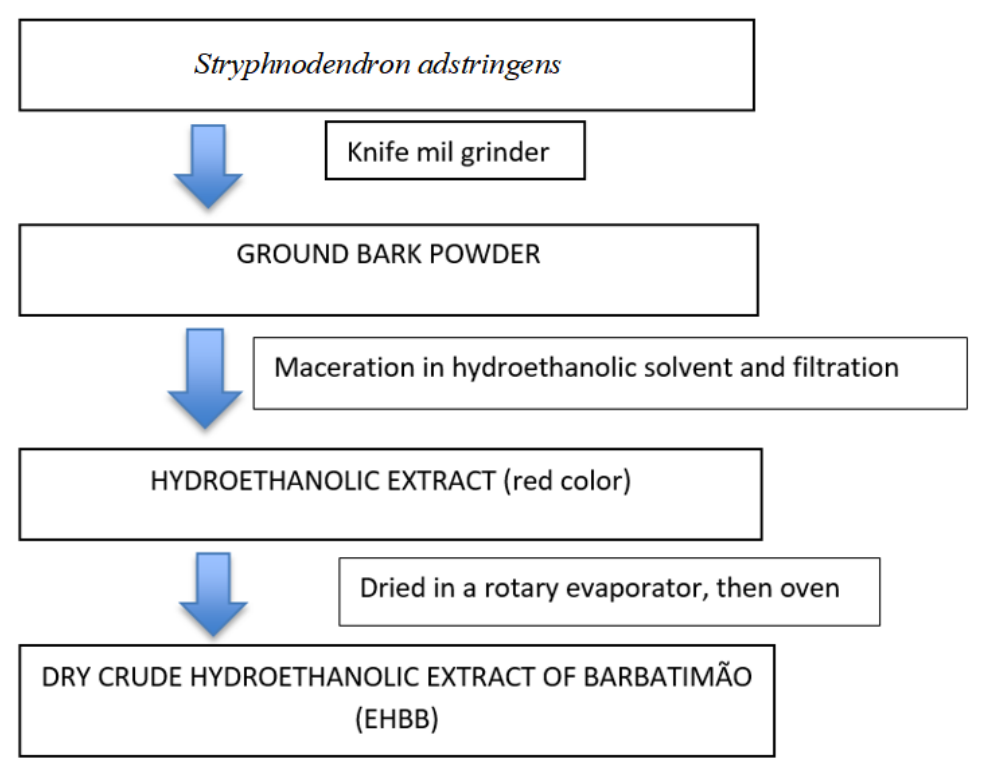

Source: Nakamura, et al., 2006

\subsection{Stock solution preparation}

Stock solution preparation $0.750 \mathrm{~g}$ of each dried EHBB (STA1, STA2, and STA3) was prepared. The material was transferred to a conical flask with $150 \mathrm{~mL}$ of water and left stirring for 30 minutes at $70^{\circ} \mathrm{C}$ on a shaking table. Then it was cooled in running water and its contents were quantitatively transferred to a $250 \mathrm{~mL}$ volumetric flask, washing and completing the volume with water. About $80 \mathrm{~mL}$ of the extract was taken and filtered through filter paper, the first $50 \mathrm{~mL}$ being discarded. 
The filtrate obtained was called the stock solution (SS). This solution was used in the quantification of total polyphenols, nonabsorbent polyphenols, total tannins and antioxidant activity.

\subsection{Total polyphenols, polyphenols, and tannins}

The content of polyphenols, non-absorbent polyphenols (PNA), and total tannins was determined. For the determination of total polyphenols (PT), $5 \mathrm{~mL}$ of the SS, described in 2.3 , were diluted with water in a $25 \mathrm{~mL}$ volumetric flask. Two milliliters of this solution were transferred, with $1 \mathrm{~mL}$ of the Folin-Ciocalteau reagent (Sigma, USA) and $10 \mathrm{~mL}$ of water, to a $25 \mathrm{~mL}$ volumetric flask, completing the volume with $14.06 \%$ sodium carbonate solution. After 15 minutes of adding the last solution, the absorbance was measured at $691 \mathrm{~nm}$ in the spectrophotometer, using water as a reference. For the determination of PNA, $10 \mathrm{~mL}$ of SS was transferred with $0.100 \mathrm{~g}$ of skin powder R (lightly chromed, FreibergForschungsinstitut, Germany) to a beaker and stirred for 60 minutes. After this time, the solution was filtered. Five milliliters of the filtrate were diluted with water to $25 \mathrm{~mL}$ in a volumetric flask. Two milliliters of this solution were transferred with 1 $\mathrm{mL}$ of the Folin-Ciocalteau reagent and $10 \mathrm{~mL}$ of water to a $25 \mathrm{~mL}$ volumetric flask, completing the volume with $14.06 \%$ sodium carbonate solution. Fifteen minutes after adding the last solution, the absorbance was measured in a spectrophotometer at $691 \mathrm{~nm}$, using water as a reference. The set of operations (extraction and dilution) was carried out while shielded from direct light. All analyzes were performed six times. The percentages were calculated using the following formulas:

$$
\begin{aligned}
& \text { PT }=15625 \times \mathrm{A}_{691} \text { PT } 1000 \times \mathrm{m} \\
& \text { PNA }=15625 \times \mathrm{A}_{691} \text { PNA } 1000 \times \mathrm{m} \\
& \mathrm{TT}=\mathrm{PT}-\mathrm{PNA}
\end{aligned}
$$

Where: $\mathrm{PT}=$ Total Polyphenols $(\%) ; \mathrm{PNA}=$ Non-absorbent polyphenols $(\%) ; \mathrm{A}_{691}=$ Absorbance measured at $691 \mathrm{~nm} ; \mathrm{m}=$ mass of the drug in $\mathrm{g}$ and $\mathrm{TT}=$ Total Tannin Content $(\%)$.

\subsection{UHPLC-MS analysis}

Chromatographic analysis of the crude extract was performed using an Ultra-High-Performance Liquid Chromatography (UHPLC-MS ${ }^{\circledR}$ Acquity, Waters, USA) with a $\mathrm{C}_{18} \mathrm{BEH}$ Acquity Waters column $(1.7 \mu \mathrm{m} \times 2.1 \mathrm{~mm} \times 50 \mathrm{~mm})$, oven temperature at $30^{\circ} \mathrm{C}$ and $7 \mu \mathrm{L}$ of each sample were injected (standard and sample). The elution was performed using a gradient with a flow of $200 \mu \mathrm{L} / \mathrm{min}$, a mobile phase of water (Milli-Q) with $0.1 \%$ of formic acid (A) and acetonitrile (Merck Darmstadt, Germany, chromatographic grade) (B). This gradient was: 0.00 min, 90\% A and 10\% B, 4.00 min $75 \%$ A, 8.00 min 0\% A, $8.51 \mathrm{~min} 90 \% \mathrm{~A}$ and $10.00 \mathrm{~min} 90 \% \mathrm{~A}$. The compounds were detected using a triple-quadrupole mass spectrometer (TQD Acquity, Waters, USA) with electrospray ionization (ESI), in the positive ion mode under the following conditions: Capillary of $3000 \mathrm{~V}$, cone $35 \mathrm{~V}$, the extractor of $1.0 \mathrm{~V}$, source temperature of $150^{\circ} \mathrm{C}$ and desolvation temperature of $300^{\circ} \mathrm{C}$. Pyrogallol and chlorogenic acid were identified by comparison of $\mathrm{m} / \mathrm{z}$ and retention times to standards (Sigma). We investigate STA1, STA2 and STA3 solutions, were found tannins.

\subsection{Antioxidant activity}

The stock solutions were used, whose soluble solids value was determined. The $0.01 \%(\mathrm{~m} / \mathrm{V})$ extracts were then obtained from the stock solutions. Eleven tubes were organized, numbering them from 0 to 10 . The volumes of alcohol and $0.01 \%$ of STA1, STA2 and STA3 were added to each tube, according to the desired dilution. The volume of 2,2-diphenyl-1picrylhydrazyl (DPPH, Sigma, EUA) was added to the 1st tube, and the timer turned on, turning it off after one minute. DPPH was added to the other tubes every 1 minute. The reading was done on a spectrophotometer 30 minutes after the addition of 
DPPH in the 1st tube at a wavelength of $517 \mathrm{~nm}$. An absorbance graph in \% of remaining DPPH versus the concentration of the stock solution $(\mu \mathrm{g} / \mathrm{mL})$ was made, and the $\mathrm{EC}_{50}$ (a dose that eliminates $50 \%$ of free radical) was calculated using the leastsquares method with GRAPH PAD PRISM 6 (USA).

\subsection{In silico studies}

Structural optimization was performed by the PM6 methods implemented in the semiempirical quantum chemistry MOPAC 2016 software package. The files containing the three-dimensional information of each structure as well as the charge information of electrostatic potential, were the input files viewed by the JMol software. The frontier orbital energy was calculated by Chem3D Ultra 8.0. Data of orbital energies, dipole moment partial charges and atomics volume were used in the comparative analysis by which it was intended to carry out qualitative studies of chemical structure and biological activity (SAR). To evaluate the pharmacokinetic properties of the designed compounds, the 2D structure of the compounds were drawn on Chemdraw Ultra 12.0. Each structure was imported and the structure smiley was entered at the interface of the website (http://swissadme.ch/). The SwissADME drug design study was run and the ADME properties/parameters were generated.

\subsection{Antimicrobial tests}

\subsubsection{Microorganisms}

The strains used in this study comprehended some clinical isolates and strains provided by culture collections like the American Type Culture Collection (ATCC). Standard Mueller-Hinton agar and Mueller-Hinton were used as culture media to determine the inhibition zones (inoculums 0.5 McFarland suspension, $1.5 \times 10^{8}$ colony forming units - CFU/mL) and MIC (Minimal Inhibitory Concentration - inoculums $5 \times 10^{5} \mathrm{CFU} / \mathrm{mL}$ ) for each strain, measured as described in CLSI/NCCLS standards, respectively. However, fastidious strains such as Streptococcus pneumoniae (S. pneumoniae) were tested in GC medium and horse-blood agar. The following bacterial strains were tested: Rib1 (Staphylococcus aureus methicillin-resistant strain MRSA clinical isolates), BEC (Staphylococcus aureus Brazilian Epidemic Clone of MRSA strain), SA (Staphylococcus aureus ATCC 29213), PN3 (Streptococcus pneumoniae of type 3 ATCC 6303), KP (Klebsiella pneumoniae ATCC13693), EC (Escherichia coli ATCC 25922), NG (Neisseria gonorrhoeae ATCC 49226) all of them from INCQS (Instituto Nacional de

Controle de Qualidade em Saúde - FIOCRUZ - Rio de Janeiro - Brazil). PseuATCC (Pseudomonas aeruginosa ATCC 27853) was from our laboratory.

\subsubsection{Antibacterial screening}

Antimicrobial activities of the stock solution were firstly screened for their inhibitory potential by the agar diffusion method, as described previously (Dickson, et al., 2006). Briefly, the test of each extract with its respective bacterial sample was performed in $\mathrm{MHA} / \mathrm{GC} / \mathrm{Blood} / \mathrm{Chocolate}$ agar by incubating at $37^{\circ} \mathrm{C}$ for 24 hours, after which time they were examined for zones of inhibition. The solvent value was deducted accordingly to get the result of the activity and subjected to the determination of their MIC by the serial dilution method according to the procedures reported previously (Dickson, et al., 2006). Briefly, stock solutions $(200 \mathrm{mg} / \mathrm{mL})$ of all extracts (STA1, STA2 and STA3) in DMSO were passed through a pyrogenic filter to sterilize the solution and serially diluted to arrive at concentrations between $2000 \mu \mathrm{g} / \mathrm{mL}$ and $100 \mu \mathrm{g} / \mathrm{mL}$. All experiments were carried out in triplicate. The extracts with inhibition zone diameter $(\mathrm{ZD}) \geq 10 \mathrm{~mm}$ were further. Determination of antibacterial activity and minimal inhibitory concentration by the technique of dilution in tubes (Iturriaga, et al., 2012). The bacterial suspension was prepared previously obeying $0.5 \mathrm{McFarland}$ scale, and negative control solutions were prepared with antibiotics. 


\subsubsection{Dilution method in tubes}

The plant extracts were prepared in-stock solution of $200 \mathrm{mg} / \mathrm{mL}$ in sterile distilled water in seven series of tubes containing $1 \mathrm{~mL}$ of Muller- Hinton broth (MHB) was prepared. In the 1st tube, $1 \mathrm{~mL}$ of each STA1, STA2 and STA3 was added. After homogenization, the mixture contained in $1 \mathrm{~mL}$ of the 1st tube was transferred to the 2nd tube, homogenized and so on until the 8th tube, which, after homogenization, discarded $1 \mathrm{~mL}$. Thus, a final volume of $1 \mathrm{~mL}$ in each tube was obtained to final concentrations of plant extracts $100 ; 50 ; 25 ; 12.5 ; 6.25 ; 3.125 ; 1.512 ; 0.78 \mathrm{mg} / \mathrm{mL}$. Also, $100 \mathrm{~mL}$ of a bacterial suspension of $10^{7} \mathrm{CFU} / \mathrm{mL}$ was subsequently added to each tube. The tubes were incubated at $36^{\circ} \mathrm{C} \pm 1{ }^{\circ} \mathrm{C}$ for 24 hours and then visually observed which tubes appeared turbid (indicating bacterial growth) and apparent (growth inhibition). To determine the MIC, and the turbidity of some layers even before adding the bacterial suspension, a sample of each tube was seeded on plates containing Mueller -Hinton Agar (MHA). These plates were incubated $36^{\circ} \mathrm{C} \pm 1^{\circ} \mathrm{C}$ for two another 4 hours and after incubation was analyzed for the presence or absence of bacterial growth, thus confirming the bactericidal or bacteriostatic action of the plant extracts. Each extract was tested in triplicate.

\subsection{Phagocytosis tests}

\subsubsection{Blood samples}

Venous blood samples from healthy volunteer donors were collected in vacutainers at the UNIPINHAL, Espírito Santo do Pinhal/SP, Brazil. All donors receive guidance concerning the purpose for which the scientific work was intended and signed terms of informed consent according to approval by the Ethics Committee of the Center Regional University of Espírito Santo do Pinhal - UNIPINHAL, Protocol no 796/14-CPE.

\subsubsection{Preparation of yeast cells}

Candida albicans and Candida kefyr (Fundação Tropical André Tozelo) were cultured for 8 hours at $37^{\circ} \mathrm{C}$ on Sabouraud glucose-agar slants (Biobrás cod:107-3) and were harvested, washed in Hank's balanced salt solution (HBSS) and counted. To opsonize the yeast cells, $100 \mu \mathrm{L}$ of pooled non-inactivated normal human $\mathrm{AB}$ serum was added to $5 \mathrm{x} 10^{6}$ yeast cells. After $30 \mathrm{~min}$, TC 199 medium (GIBCO, Grand Island, NY, U.S.A.) was added to give a final concentration of $5 \times 10^{6}$ cells $/ \mathrm{mL}$.

\subsubsection{Preparation of S. adstringens solutions}

A stock solution of $S$. adstringens (STA3) was prepared in HBSS-0.1\% DMSO at $4 \mathrm{mg} / \mathrm{mL}$ and stored at $4^{\circ} \mathrm{C}$. Sample three (STA3) had the best result in antibacterial activity. Therefore, this sample was chosen to test its phagocytic and lytic function against C. albicans and C. kefyr. Desired dilutions were made for S. adstringens stocks with TC 199 medium.

\subsubsection{Isolation of polymorphonuclear cells and study of their phagocytic and lytic functions}

Blood obtained by venipuncture was immediately placed on a clean glass slide, the edges of which were sealed. No anticoagulant was used. After two hours of incubation in a humid chamber at $37^{\circ} \mathrm{C}$, the blood clot was removed, and the slide was washed with warm TC 199 medium. The polymorphonuclear leukocytes (PMN) cells adhering to the glass slides were incubated for $30 \mathrm{~min}$ at $37^{\circ} \mathrm{C}$ with $1 \mathrm{~mL}$ of a solution of $1,2,3$, or $4 \mathrm{mg} / \mathrm{mL}$ S. adstringens. After incubation time, the PMN cells were then incubated with $1 \mathrm{~mL}$ of the $5 \times 10^{6}$ cells $/ \mathrm{mL}$ suspension of opsonized yeast cells. After a 30 min incubation, the yeast cells remaining in suspension were removed by gently washing the slides three times with warm TC 199 medium. The slides were then air-dried and stained with Giemsa before evaluating Candida phagocytosis and killing by the adherent cells. 
Phagocytic activity was expressed as the number of antigens phagocytized per 100 PMN cells. Lytic activity was expressed as the percentage of "ghost" images (dead yeast cells) out of the total number of phagocytized Candida cells.

\subsection{Statistical analysis}

All data represent the mean \pm standard deviation (SD) of experiments run in triplicate. Comparisons of data among all groups have been performed by analysis of variance Tukey's test. All $P$ values represent the two-sided test of statistical significance. Statistical significance was assigned when $P<0.05$.

\section{Results and Discussion}

\subsection{Chemical findings and antioxidant activity}

The content of polyphenols, non-adsorbent polyphenols, and total tannins is shown in Table 1 for the STA1, STA2, STA3 and EHBB. The antioxidant activity $\left(\mathrm{EC}_{50}\right.$ in $\left.\mu \mathrm{g} / \mathrm{mL}\right)$ was evaluated only for STA solutions.

Table 1. Content of polyphenols, non-adsorbent polyphenols, and total tannins in the extracts of S. adstringens (\% m/V). The antioxidant activity $\left(\mathrm{EC}_{50}\right.$ in $\left.\mu \mathrm{g} / \mathrm{mL}\right)$ was evaluated only for STA samples.

\begin{tabular}{cccccc}
\hline & & \multicolumn{2}{c}{ Stock solution $(\mathrm{SS})(\boldsymbol{\%} \mathbf{m} / \mathbf{V})$} & & EHBB $(\boldsymbol{\%} \mathbf{~ m} / \mathbf{m})$ \\
\hline Sample & \% Polyphenols & $\begin{array}{c}\text { \% Polyphenols no } \\
\text { adsorbents }\end{array}$ & \% Tannins & EC $50(\boldsymbol{\mu g} / \mathbf{m L})$ & $\%$ Tannins \\
\hline STA1 & $0.530 \pm 0.032$ & $0.377 \pm 0.015$ & $0.153 \pm 0.025$ & $9.38 \pm 0.65$ & $20.460 \pm 3.392$ \\
STA2 & $0.527 \pm 0.006$ & $0.391 \pm 0.022$ & $0.136 \pm 0.018$ & $9.28 \pm 0,58$ & $18.104 \pm 2.426$ \\
STA3 & $0.530 \pm 0.006$ & $0.394 \pm 0.020$ & $0.255 \pm 0.031$ & $8.86 \pm 0.80$ & $28.837 \pm 0.484$ \\
\hline
\end{tabular}

Source: Authors (2022).

All three samples contained two bioactive phenolic compounds (pyrogallol 1 and chlorogenic acid 2), albeit in different amounts. Whereas STA1 presented the most significant peak area of pyrogallol and smallest of chlorogenic acid, STA3 presented the inverse proportions, and STA2 presented an intermediate profile. Both compounds would be detected in the analysis of the total phenolic compounds (Figure 1). 
Figure 1: Extracted ion chromatograms of $m / z 125$ corresponding to pyrogallol in STA1 (A), STA2 (C), and STA3 (E), Rt 1.0 min. Extracted ion chromatograms of $m / z, 353$ corresponding to chlorogenic acid in STA1 (B), STA2 (D), and STA3 (F), Rt 1.9 min. Area of the peaks shown on the chromatograms.

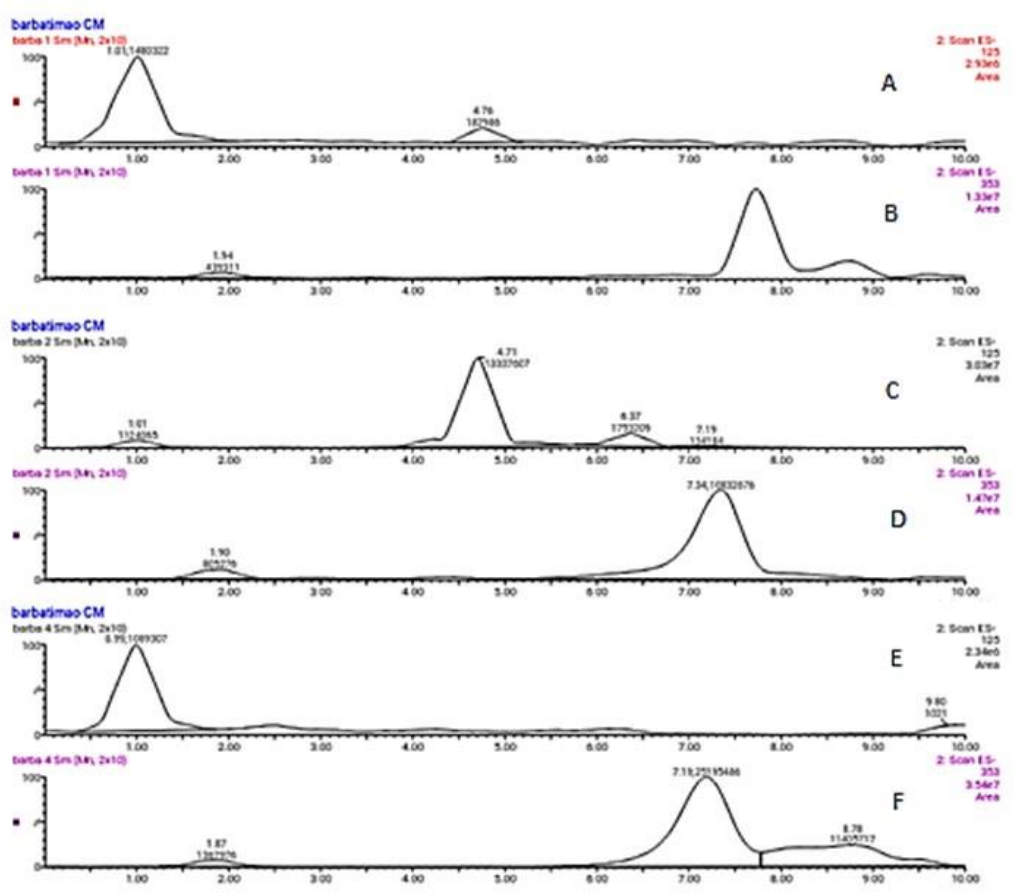

Source: Authors (2022).

\subsection{In silico studies}

The pharmacokinetic properties for the compounds 1 and 2 were predicted through Swiss ADMET Predictor (http://www.swissadme.ch/), a designed program of the computer for estimating pharmacokinetic parameters/properties of drug-like compounds from their molecular structures called the ADMET which referred to Absorption, Distribution, Metabolism, Excretion/Elimination, and Toxicity (Daina, et al., 2017). We considered the Lipinski Rules proposed four ADMET properties, also called of "Rule of Five". This rule of five was the authentic and "most well-known rule-based filter" of drug-likeness which is used to examine if the compound can be well absorbed orally or not. The rule of five includes: Molecular weight $(\mathrm{MW}) \leq 500$; Octanol/water partition coefficient (iLOGP) $\leq 5$; Number of hydrogen bond donors (HBDs) $\leq$ 5 (accounted in function of $\mathrm{NH}$ or $\mathrm{OH}$ groups in the molecule); and Number of hydrogen bond acceptors (HBAs) $\leq 10$ (accounted in function of $\mathrm{N}$ or $\mathrm{O}$ atoms in the molecule). Under the Rule of Five, a molecule can only be orally active/absorb if it does not violate any two or more of the above rules. Table 2 represented some of the ADMET properties/parameters (Lipinski, et al., 2001). 
Table 2. ADMET parameters found for the compounds 1 and 2 using the free toolbar SwissADMET Predictor.

\begin{tabular}{|c|c|c|c|c|c|c|c|c|c|c|}
\hline \multirow{2}{*}{ Compound } & \multicolumn{5}{|c|}{ Lipinski parameter } & \multirow{2}{*}{$\begin{array}{c}\text { TPSA } \\
\left(\AA^{2}\right)\end{array}$} & \multirow{2}{*}{$\operatorname{LogS}$} & \multirow{2}{*}{ Class } & \multirow{2}{*}{$\begin{array}{c}\% \text { ABS } \\
(\%)\end{array}$} & \multirow{2}{*}{$\begin{array}{l}\text { Drug } \\
\text { Score }\end{array}$} \\
\hline & $\begin{array}{c}\text { MW } \\
\text { (g/mol) }\end{array}$ & HBDs & HBAs & iLOGP & $\mathbf{n V}$ & & & & & \\
\hline 1 & 126.11 & 3 & 3 & 0.97 & 0 & 60.69 & -1.44 & Soluble & 88.06 & 0.55 \\
\hline 2 & 354.31 & 6 & 9 & 0.87 & 1 & 164.75 & -1.62 & Soluble & 52.16 & 0.11 \\
\hline
\end{tabular}

Physicochemical properties calculated on SwissADME: MW: molecular weight; HBDs: hydrogen bonding donor; HBAs: hydrogen bonding acceptor; iLogP: octanol/water partition coefficient; $n V$ : number of violations; TPSA: total polar surface area; LogS: coefficient of solubility determined by the ESOL method; Class: insoluble $<-10<$ poor $<-6<$ moderately $<-4<$ soluble $<-2<$ very $<0<$ highly; \%ABS was expressed by the equation \%ABS $=109-(0.345 \times$ TPSA $)$. Source: Authors (2022).

According to the results obtained by the in silico approach, compound 1 complies with the rules of the Lipinski Rule, indicating a good oral bioavailability, once this substance is in an oral pharmaceutical form. The TPSA value obtained for this compound is below $140 \AA^{2}$, indicating an excellent permeability of the compound on the cell plasma membrane. The percentage of absorption showed a result for the compound, with $60.69 \%$. The calculated $\operatorname{LogS}$ was -1.44 , which is within the desired range considering that many substances already approved for use in therapy have a value greater than -4.00 , and from this result, compound $\mathbf{1}$ is considered soluble. The score of compound $\boldsymbol{1}$ for the Drug Score was determined by combining records of similarity with already approved drugs, lipophilicity, solubility, molecular weight and toxicity risks in a single numerical value, which ranges from 0.0 to 1.0 and can be used to predict the overall potential of a compound as a new drug candidate. The value obtained in this approach was 0.55 , suggesting that these compounds have the potential to become new drug candidates. In relation to compound 2 , the calculations showed a violation in relation to the rules of Lipinski. The number of hydrogen donor bonds exceeds that allowed. In addition, the TPSA value exceeds that indicated so that this compound has a good absorption across cell membranes. Another important point found in the calculations is the alert for PAINs, an index that shows the tendencies of this compound to react not specifically with numerous biological targets, suggesting a low possibility of selectivity.

The Molecular Electrostatic Potential Map (MEP) was also obtained. The MEP is a classic tool in the analysis of chemical activity, especially in the drug designer. In most cases, MEP is used as a qualitative approach. The MPE is based on the calculated properties of the charge density directly from the function of the molecular wave and measures the interaction of a positively charged point with the nuclei and electrons of a molecule. The interaction between the molecules occurs between regions of opposite electrostatic potentials. The improved accuracy of PM6 are particularly valuable for generating electronic descriptors for qualitative structure activity relationships (QSAR).

By representing the charge distribution of compound 2, it is possible to observe a low electron density (red region of the map) mainly around the hydrogens of the phenolic groups. This low electronic density is not so accentuated in the other hydrogens in the aromatic ring. When looking at the map (Figure 2) in general, there is no region with a high electronic charge (red region of the map), only a small reddish region is observed around the aromatic electrons. 
Figure 2. Electrostatic potential maps calculated onto the Connolly surfaces obtained for compound 1.
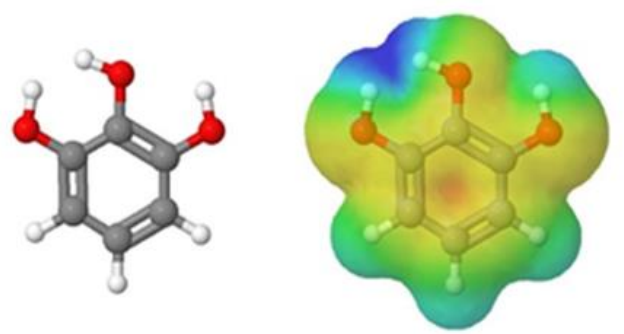

Source: Authors (2022).

The MEP of compound 2 shows a high concentration of electrons (red region of the map) mainly on the oxygen of the carbonyls, both of the carboxylic acid and of the ester group. The low electronic density (blue region of the map) is mainly on the hydrogens of the phenolic groups, but also on a lower density on the hydrogens belonging to the aromatic ring (Figure 3).

Figure 3. Electrostatic potential maps calculated onto the Connolly surfaces obtained for compound 2.
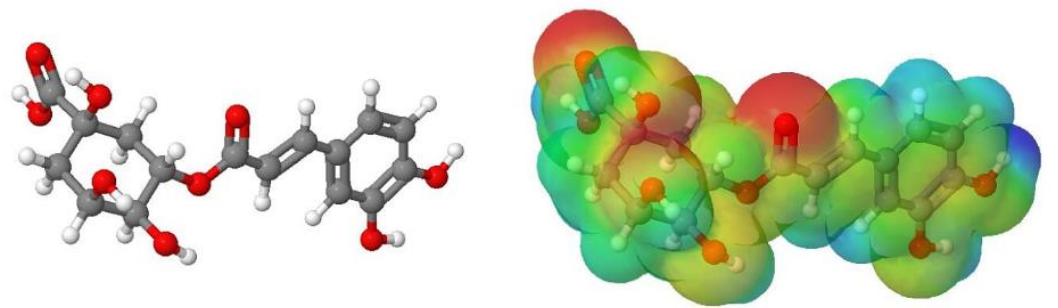

Source: Authors (2022).

The energies of the frontier orbitals, that is, the highest occupied molecular orbital (HOMO) and the lowest unoccupied molecular orbital (LUMO), were also calculated. These results are a quantitative descriptive that are widely used that play an important role in the chemistry reaction and in the formation of several charge complexes. The energy of HOMO is directly related to the potential ionization of the compound and the ability of the molecule to create nucleophiles. The energy of LUMO is directly related to electronic affinity, characterized by the susceptibility of the compound to nucleophiles in relation to them. The difference between the energies of the HOMO-LUMO orbitals, called GAP, is an important indicator of molecular stability. Molecules with a low GAP value are generally reactive, while molecules with a high GAP value indicate high stability and low possibility to react with anthers compounds (Zhang \& Musgrave, 2007). Table 3 presents the values calculated for the HOMO and LUMO orbitals of compounds 1 and $\boldsymbol{2}$ as well as the GAP value. The electronic density of frontier orbitals is a useful way for the detailed characterization of donor-acceptor interactions and the most of chemistry reactions occur at the location of the highest electronic density in the frontier orbitals. 
Table 3. Frontier orbitals calculated for compounds 1 and 2 and their GAP values.

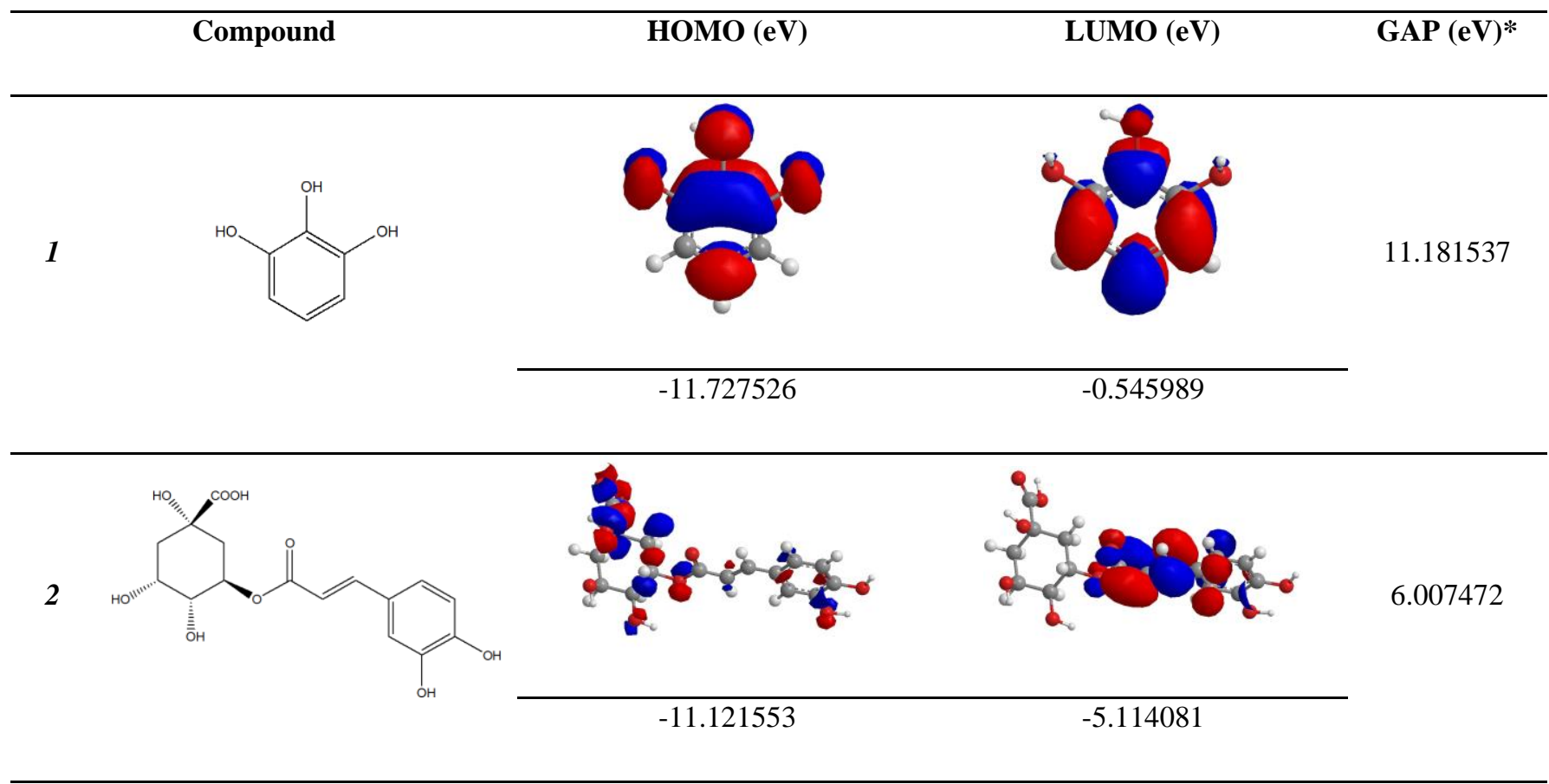

* The GAP calculation was performed from the difference of the energy value of the LUMO orbital by the energy value of the HOMO orbital

Considering that the higher the energy of HOMO, the greater the electron-donor capacity and that the lower the energy of LUMO, the lower the resistance to accept electrons, we can define that the compound $\mathbf{1}$, which has the highest GAP value may have high molecular stability. Compound 2, which has the lowest GAP value, can be considered the least stable compound. Thus, it is possible to predict that compound 1 may demonstrate greater biological activity, corroborating the pharmacokinetic results obtained. Source: Authors (2022).

\subsection{Antibacterial activity}

The results obtained with the extracts of $S$. adstringens after performing the in vitro agar diffusion and serial dilution methods to determine the minimum inhibitory concentration (MIC), showed antimicrobial activity against microorganisms: Rib1Staphylococcus aureus methicillin-resistant strain MRSA clinical isolates; BEC- Staphylococcus aureus Brazilian Epidemic Clone of MRSA strain; SA- Staphylococcus aureus ATCC 29213; PseuATCC- Pseudomonas aeruginosa ATCC 27853; PN3Streptococcus pneumoniae of type3 ATCC 6303; KP- Klebsiella pneumoniae ATCC13693; EC- Escherichia coli ATCC 25922; NG - Neisseria gonorrhoeae ATCC 49226 (Tables 4 and 5) The extracts of S. adstringens demonstrated activity against other critical bacterial pathogens like Streptococcus pneumoniae, and also against multiresistant bacteria as MRSA and Pseudomonas aeruginosa (Table 4). Table 5 shows the means of the MIC values for the three S. adstringens extracts and the ampicillin antibiotic control. 
Table 4. Mean values of the microbial growth inhibition zone in mm, using the agar diffusion method. Positive controls Ampicillin $(10 \mu \mathrm{g})-2 \mathrm{~mm}$ and Chloramphenicol $(30 \mu \mathrm{g}) 10.3 \mathrm{~mm}$.

\begin{tabular}{cccc}
\hline Bacterial Strain & \multicolumn{2}{c}{ Growth inhibition zone $(\mathbf{m m})$ of S. adstringens extracts } \\
& STA1 & STA2 & STA3 \\
\hline Rib 1 & 15 & 12 & 15 \\
BEC & 16 & 13 & 18 \\
SA & 17 & 11.3 & 15 \\
PseuATCC & - & - & - \\
PN3 & 12 & 14.3 & 16 \\
KP & 7.6 & 7.6 & 17.3 \\
EC & 13.6 & 7.3 & 14 \\
NG & 8.3 & 10.3 & 13.6 \\
\hline
\end{tabular}

Rib1- Staphylococcus aureus methicillin-resistant strain MRSA clinical isolates; BEC- Staphylococcus aureus Brazilian Epidemic Clone of MRSA strain; SA- Staphylococcus aureus ATCC 29213; PseuATCC- Pseudomonas aeruginosa ATCC 27853; PN3- Streptococcus pneumoniae of type3 ATCC 6303; KP- Klebsiella pneumoniae ATCC13693; EC-Escherichia coli ATCC 25922; NG - Neisseria gonorrhoeae ATCC 49226. Source: Authors (2022).

Table 5. Minimal Inhibitory Concentration (MIC) $(\mathrm{mg} / \mathrm{mL})$ of extracts. Positive control Ampicillin $(10 \mu \mathrm{g})$.

\begin{tabular}{cccc}
\hline Bacterial Strain & \multicolumn{3}{c}{ MIC $(\mathbf{m g} / \mathbf{m L})$ of S. adstringens extracts s } \\
& STA1 & STA2 & STA3 \\
\hline Rib 1 & 12.5 & 0.78 & 3.125 \\
BEC & 25 & 6.25 & 3.125 \\
SA & 25 & 25 & 3.125 \\
PseuATCC & - & - & - \\
PN3 & 12.5 & 50 & 0.78 \\
KP & 50 & 50 & 12.5 \\
EC & 12.5 & 6.25 & 1.562 \\
NG & - & - & 3.125 \\
\hline
\end{tabular}

Rib1- Staphylococcus aureus methicillin-resistant strain MRSA clinical isolates; BEC- Staphylococcus aureus Brazilian Epidemic Clone of MRSA strain; SA- Staphylococcus aureus ATCC 29213; PseuATCC- Pseudomonas aeruginosa ATCC 27853; PN3- Streptococcus pneumoniae of type3 ATCC 6303; KP- Klebsiella pneumoniae ATCC13693; EC- Escherichia coli ATCC 25922; NG - Neisseria gonorrhoeae ATCC 49226. Source: Authors (2022).

The agar diffusion method was employed as it is a commonly applied method to test for antibacterial activity in natural and synthetic products (Mohammadzadeh, et al., 2012). The effect of S. adstringens on phagocytosis and intracellular killing of $C$. albicans and $C$. kefyr by neutrophils is presented in Figures 4 and 5. These results demonstrate that STA3 also has important activity in the immune system, acting on polymorphonuclear cells in a dose-dependent manner. 
Figure 4: (A) Phagocytosis of $C$. albicans by neutrophils incubated with $1,2,3$, and $4 \mathrm{mg} / \mathrm{mL}$ of $S$. adstringens $(\mathrm{STA} 3)(\mathrm{n}=$ $6)$.

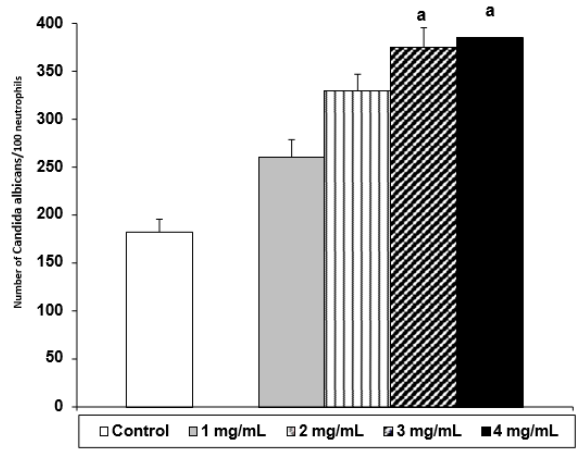

A

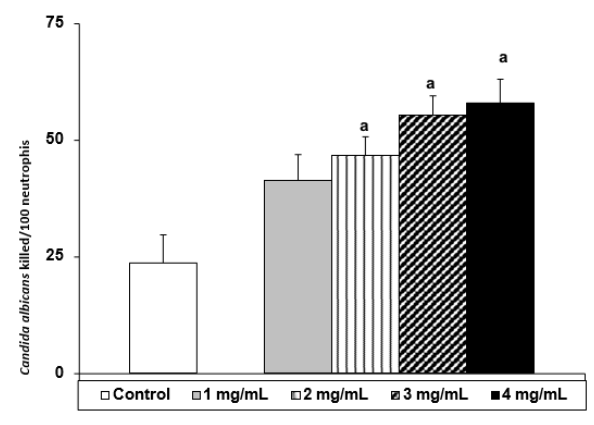

B

(A) Values are presented as mean \pm S.D. ${ }^{\text {a }} \mathrm{P}<0.05$, compared with control. (B) Killing of C. albicans by neutrophils incubated with $1,2,3$, and $4 \mathrm{mg} / \mathrm{mL}$ of $S$. adstringens (STA3) $(\mathrm{n}=6)$. (B) Values are presented as mean \pm S.D. ${ }^{a} \mathrm{P}<0.05$, compared with control; ${ }^{b} \mathrm{P}<0.05$, compared with control, 1 and $2 \mathrm{mg} / \mathrm{mL}$. Source: Authors (2022).

Figure 5: (A) Phagocytosis of C. kefyr by neutrophils incubated with 1, 2, 3, and $4 \mathrm{mg} / \mathrm{mL}$ of S. adstringens $($ STA3) (n = 6).

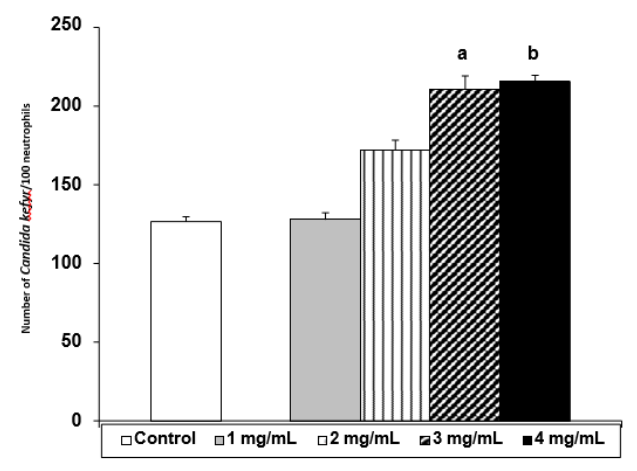

A

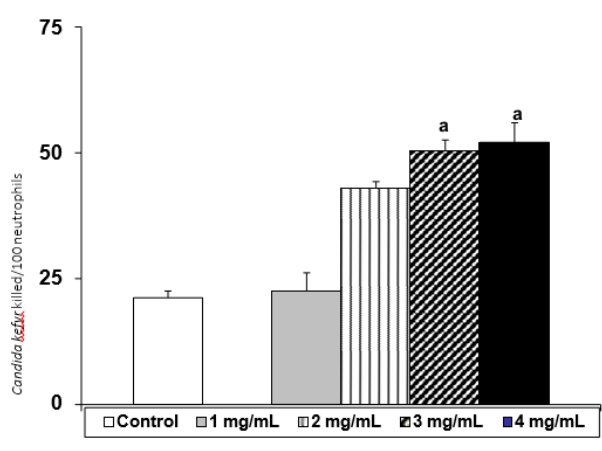

B

Values are presented as mean \pm S.D. ${ }^{a} \mathrm{P}<0.05$, compared with control; ${ }^{\mathrm{b}} \mathrm{P}<0.05$, compared with control, 1 and $2 \mathrm{mg} / \mathrm{mL}$. (B) Killing of $C$. kefyr by neutrophils incubated with $1,2,3$, and $4 \mathrm{mg} / \mathrm{mL}$ of $S$. adstringens $(\mathrm{STA} 3)(\mathrm{n}=6)$. (B) Values are presented as mean \pm S.D. ${ }^{a} \mathrm{P}<0.05$, compared with control; ${ }^{b} \mathrm{P}<0.05$, compared with control, 1 and 2 mg/mL. Source: Authors (2022).

The consumption of medicinal herbs in natura or adequately prepared has been showing considerable growth in several countries. This trend can be explained by different factors, among them the high cost and the undesirable effects of synthetic drugs, consumer preference for "natural products," scientific certification of the pharmacological properties of plant species, the development of new analytical methods made available to the control of quality, the development of new forms of preparation and administration of herbal products and a better chemical, pharmacological and clinical knowledge of drug plants and their derivatives (Calixto, 2019). As stated in the results of this work, tannins are present S. adstringens. Tannins are complex phenolic substances soluble in water with a molecular weight between 300 and 3000 Daltons but also form waterinsoluble complexes with alkalis, gelatin, and other proteins (Fraga-Corral, et al., 2020a). Widely found in plant products, they 
are consumed daily in food and also occur in a variety of medicinal herbs. The overall daily intake of tannins is estimated at 400-1000 mg. Concerning the tannin content found in the STA solutions and EHBB, they are following the literature (Huang, et al., 2018). Several published works deal with the biological activity of S. adstringens, but few about the quality control of plant drugs and extracts. The results presented by Sanches, et al. (2005) demonstrated the antioxidant capacity of extracts of $S$. adstringens obtained with different solvents and fractions, using the TLC technique by spraying DPPH (Sanches, et al., 2005). Vandeputte, et al. (2017) reported the antioxidant activity of a fraction of the aqueous extract of S. adstringens, a value following those shown in the present study (Vandeputte, et al., 2017). The $\mathrm{EC}_{50}$ found it was $6.70 \pm 0.32 \mu \mathrm{g} / \mathrm{mL}$ and the $\mathrm{EC}_{50}$ value for ascorbic acid was $5.01 \pm 0.18 \mu \mathrm{g} / \mathrm{mL}$. Other authors reported the antioxidant activity of an aqueous extract of $S$. adstringens as $3.81 \pm 0.02 \mu \mathrm{g} / \mathrm{mL}$ (Baldivia, et al., 2018).

Two phenolic compounds were identified in all the extracts as pyrogallol and chlorogenic acid by UHPLC-MS. Both compounds would be detected by the assay for total phenolics and participate actively in the antioxidant activity of the samples. Pyrogallol may be incorporated in both hydrolysable and condensed tannins and would also be detected in the tannin assay, whereas chlorogenic acid would not. The total phenolic compounds of the three samples are equivalent, but the absorbent and non-absorbent phenolics vary between samples. Indeed, a significant number of other phenolic compounds are also present in these extracts and contribute to these results. In relation to the in silico results of compounds $\mathbf{1}$ and $\mathbf{2}$, we can conclude that when analyzed alone, compound 1 exhibited a greater probability of presenting beneficial effects, when administered orally, as it does not violate any Lipinski Rule and is the most stable compound, when we compare its GAP energy to compound 2. In addition, compound 2, showed potential for acting as PAINs, in the organism.

Various reports on the cancer-fighting properties and protective action of DNA, in addition to the lack of adverse effects of these compounds, even at high doses, indicate their promising use as chemopreventive agents (Choudhari, et al., 2020). The inhibitory effects of tannins on bacteria can be explained by inhibition of microbial enzymes and complexation with enzymatic substrates, action on the cell membranes of microorganisms or complexation with metal ions, thereby decreasing the availability of these elements are essential for the metabolism of microorganisms (Othman, et al., 2019). As for the total phenolics, was reported that the total phenolic compounds from the aqueous extract of leaves, bark, and hydroalcoholic extract of $S$. adstringens Mart. was not statistically different (Marinho, et al., 2022). Still, the plants belonging to the Leguminosae family are abundant in flavonoids, some of which act in the process of defense against pathogenic microorganisms (Dong \& Song, 2020). These substances promote a vast range of pharmacological actions biochemical, including anti-inflammatory activity, antiallergic, antimicrobial, hepatoprotective anthelmintic, antithrombic, antiviral, and as ascorbate savers (Mrityunjaya, et al., 2020). It was also observed that the physicochemical properties of compounds might influence the diffusion of the same in the culture medium and, thus, interfere with the results of the evaluation. This fact could justify differences in the inhibition halos between the three samples and the MIC. About the quality of plant raw materials during production/storage, the factors that may interfere more frequently are adulteration, non-uniformity of chemical composition and contaminants like dust, heavy metals, among others (Ghabraie, et al., 2016). Adulteration may be due to the replacement of the correct part of the plant, contamination with other plant species, or total replacement of the plant (Xu, et al., 2019).

Also, tannin content can vary significantly depending on the method of extraction employed. Concerning the Barbatus genus, soils with low fertility chemistry and rainy seasons are associated with higher levels of total phenols and tannins (FragaCorral, et al., 2020b).

Several plants used in traditional medicine produce natural substances that exhibit antimicrobial and immunomodulatory activities. Thus, studies that seek for antibacterial properties present in plants has been widely stepped up. 
Phagocytes are regarded as the first cell lines that participate in the immune response and can be activated by a large number of stimuli. One of the functions of these cells is phagocytosis and the generation of reactive oxygen species (Kolodziej, 2011). Phagocytosis is one of the main mechanisms of the destruction of bacteria and begins with the binding of the particle or organism to the cell membrane. This interaction can occur through nonspecific receptors without the presence of immunological factors. However, the process of phagocytosis can be potentiated by immunomodulatory substances, like proteins present in bodily fluids or substances present in plants (Labro, 2000). Two mechanisms can mediate the destruction of microorganisms after phagocytosis: oxidative metabolism with the production of active oxygen metabolites or release of lysosomal enzymes (Labro, 2000). The role of ROS generated during cellular metabolism has been relatively studied. These reactive components that are generated by reduction of the univalent consecutive oxygen molecule, producing water and three active intermediaries: the superoxide anion $\left(\mathrm{O}_{2}^{-}\right)$, hydrogen peroxide $\left(\mathrm{H}_{2} \mathrm{O}_{2}\right)$ and the hydroxyl radical $\left(\mathrm{OH}^{-}\right)$and participate in immunological processes, inflammatory reactions, lipid peroxidation and alterations in deoxyribonucleic acid (DNA) (Das \& Roychoudhury, 2014). It is believed that the release of reactive oxygen species is associated with the process of phagocytosis and microbicide activity intended to eliminate pathogens. Once formed, the superoxide can reduce cytochrome and be oxidized or removed by the action of a specific enzyme, superoxide dismutase (SOD). The function of superoxide dismutase seems to be related to the protection of aerobic organisms against potentially harmful effects of superoxide anion-several types of research about the mechanism of antimicrobial action of phagocytes. In phagocytosis, the activation of oxidative metabolism occurs as a result of cell stimulation. It is believed that the release of reactive oxygen species is associated with the process of phagocytosis and microbicide activity intended to eliminate pathogens (Wang, et al., 2018).

The results demonstrate that $S$. adstringens incubated with PMN plus $C$. albicans significantly increased $(P<0.05)$ their phagocytic activities in a dose-dependent manner when compared to those of control PMN. When $C$. kefyr was used as an antigen, these two neutrophil functions were increased $(P<0.05)$ only with $S$. adstringens at 3 and $4 \mathrm{mg} / \mathrm{mL}$. In this study, we have demonstrated that phagocytosis and killing of both Candida species were significantly increased in the presence of $S$. adstringens $(1,2,3$, and $4 \mathrm{mg} / \mathrm{mL}$ to $C$. albicans; 3 and $4 \mathrm{mg} / \mathrm{mL}$ to $C$. kefyr). It is known that superoxide generation by neutrophils exerts an essential role in the host defense system against microbial infection (Teng, et al., 2017). The enzyme responsible for $\mathrm{O}_{2}^{-}$generation, called NADPH oxidase (or respiratory burst oxidase), is dormant in resting cells and becomes active upon cell activation (El-Benna, et al., 2008). According to Videla, et al. (1990), the increased rate of microsomal superoxide anions products can be explained in terms of an increased microsomal oxidative capacity secondary to cytochrome P-450 induction, when the system operates with endogenous cofactors (NADPH and $\left.\mathrm{O}_{2}\right)$ in the absence of exogenous substrates. Besides, S. adstringens compounds can alter the calcium homeostasis; it suggests that the presence of tannin on the S. adstringens can be responsible for this effect. Factors involved in this cycle are thought to be associated with the activation of superoxide anion production by phagocytic cells. It is well known that the enhanced generation of superoxide anion and probably other species of $\mathrm{O}_{2}$ may induce lipid peroxidative process in hepatocytes as well as polymorphonuclear leukocytes (Videla, et al., 1990). These data taken together suggest that S. adstringens enhances antigen-induced phagocytosis of polymorphonuclear leukocyte "in vitro." Therefore, an increase in the number of these cells in the site of an infection following S. adstringens administration in vivo might be expected, thereby mediating destruction or inhibition of microbial growth.

\section{Conclusion}

Concluding, all these extracts showed potent antibacterial activity against an extraordinary opportunist and pathogenic bacteria. The present study shows that these data taken together suggest that $S$. adstringens enhances antigen-induced phagocytosis of polymorphonuclear leukocyte in vitro. Therefore, an increase in the number of these cells in the site of 
infection following $S$. adstringens administration in vivo might be expected, thereby mediating destruction or inhibition of microbial growth. Also, it was possible to verify the importance of higher quality control as an assurance of the effects of $S$. adstringens extracts.

\section{Conflict of interest}

Authors declare that there are no conflicts of interest, and that the research does not involve humans and/or animals.

\section{References}

Baldivia, D. D., Leite, D. F., Castro, D. T., Campos, J. F., Santos, U. P., Paredes-Gamero, E. J., Carollo, C. A., Silva, D. B., De Picoli Souza, K., \& Dos Santos, E. L. (2018). Evaluation of In Vitro Antioxidant and Anticancer Properties of the Aqueous Extract from the Stem Bark of Stryphnodendron adstringens. In International Journal of Molecular Sciences, 18(8).

Calixto, J. B. (2019). The role of natural products in modern drug discovery.Calixto, J. B. (2019). The role of natural products in modern drug discovery. Anais Da Academia Brasileira de Ciencias, 91, 1-7.

Choudhari, A. S., Mandave, P. C., Deshpande, M., Ranjekar, P., \& Prakash, O. (2020). Phytochemicals in Cancer Treatment: From Preclinical Studies to Clinical Practice. Frontiers in Pharmacology, 10.

Daina, A., Michielin, O., \& Zoete, V. (2017). SwissADME: a free web tool to evaluate pharmacokinetics, drug-likeness and medicinal chemistry friendliness of small molecules. Scientific Reports, 7(1), 42717.

Das, K., \& Roychoudhury, A. (2014). Reactive oxygen species (ROS) and response of antioxidants as ROS-scavengers during environmental stress in plants. Frontiers in Environmental Science, 2.

Dickson, R. A., Houghton, P. J., Hylands, P. J., \& Gibbons, S. (2006). Antimicrobial, resistance-modifying effects, antioxidant and free radical scavenging activities of Mezoneuron benthamianum Baill., Securinega virosa Roxb. \&Wlld. and Microglossa pyrifolia Lam. Phytotherapy Research : PTR, 20(1), 41-45.

Dong, W., \& Song, Y. (2020). The Significance of Flavonoids in the Process of Biological Nitrogen Fixation. International Journal of Molecular Sciences, $21(16), 5926$.

El-Benna, J., Dang, P. M.-C., \& Gougerot-Pocidalo, M.-A. (2008). Priming of the neutrophil NADPH oxidase activation: role of p47phox phosphorylation and NOX2 mobilization to the plasma membrane. Seminars in Immunopathology, 30(3), 279-289.

Felfili, J. M., Nogueira, P. E., Silva Júnior, M. C. da, Marimon, B. S., \& Delitti, W. B. C. (2002). Composição florística e fitossociologia do cerrado sentido restrito no município de água boa - MT. Acta Botanica Brasilica, 16(1), 103-112.

Flores, G., Dastmalchi, K., Wu, S.-B., Whalen, K., Dabo, A. J., Reynertson, K. A., Foronjy, R. F., D Armiento, J. M., \& Kennelly, E. J. (2013). Phenolic-rich extract from the Costa Rican guava (Psidium friedrichsthalianum) pulp with antioxidant and anti-inflammatory activity. Potential for COPD therapy. Food Chemistry, 141(2), 889-895.

Fraga-Corral, M., García-Oliveira, P., Pereira, A. G., Lourenço-Lopes, C., Jimenez-Lopez, C., Prieto, M. A., \& Simal-Gandara, J. (2020b). Technological Application of Tannin-Based Extracts. Molecules (Basel, Switzerland), 25(3), 614.

Ghabraie, M., Vu, K. D., Tata, L., Salmieri, S., \& Lacroix, M. (2016). Antimicrobial effect of essential oils in combinations against five bacteria and their effect on sensorial quality of ground meat. LWT - Food Science and Technology, 66, 332-339.

Huang, Q., Liu, X., Zhao, G., Hu, T., \& Wang, Y. (2018). Potential and challenges of tannins as an alternative to in-feed antibiotics for farm animal production. Animal Nutrition (Zhongguо Хи Ми Shou Yi Хие Hui), 4(2), 137-150.

Ishida, K., Rozental, S., de Mello, J. C. P., \& Nakamura, C. V. (2009). Activity of tannins from Stryphnodendron adstringens on Cryptococcus neoformans: effects on growth, capsule size and pigmentation. Annals of Clinical Microbiology and Antimicrobials, 8, 29.

Iturriaga, L., Olabarrieta, I., \& de Marañón, I. M. (2012). Antimicrobial assays of natural extracts and their inhibitory effect against Listeria innocua and fish spoilage bacteria, after incorporation into biopolymer edible films. International Journal of Food Microbiology, 158(1), 58-64.

Kolodziej, H. (2011). Antimicrobial, Antiviral and Immunomodulatory Activity Studies of Pelargonium sidoides (EPs(®) 7630) in the Context of Health Promotion. Pharmaceuticals (Basel, Switzerland), 4(10), 1295-1314.

Labro, M. T. (2000). Interference of antibacterial agents with phagocyte functions: immunomodulation or "immuno-fairy tales"? Clinical Microbiology Reviews, 13(4), 615-650.

Lipinski, C. A., Lombardo, F., Dominy, B. W., \& Feeney, P. J. (2001). Experimental and computational approaches to estimate solubility and permeability in drug discovery and development settings. Advanced Drug Delivery Reviews, 46(1-3), 3-26.

Marinho, T. A., Oliveira, M. G., Menezes-Filho, A. C. P., Castro, C. F. S., Oliveira, I. M. M., Borges, L. L., Melo-Reis, P. R., \& Silva-Jr, N. J. (2022). Phytochemical characterization, and antioxidant and antibacterial activities of the hydroethanolic extract of anadenanthera peregrina stem bark. Brazilian Journal of Biology, 82, 1-12. 
Research, Society and Development, v. 11, n. 2, e35911225748, 2021

(CC BY 4.0) | ISSN 2525-3409 | DOI: http://dx.doi.org/10.33448/rsd-v11i2.25748

Mellini, M., Di Muzio, E., D’Angelo, F., Baldelli, V., Ferrillo, S., Visca, P., Leoni, L., Polticelli, F., \& Rampioni, G. (2019). In silico Selection and Experimental Validation of FDA-Approved Drugs as Anti-quorum Sensing Agents. Frontiers in Microbiology, 10, 2355.

Mohammadzadeh, T., Sadjjadi, S., Habibi, P., \& Sarkari, B. (2012). Comparison of Agar Dilution, Broth Dilution, Cylinder Plate and Disk Diffusion Methods for Evaluation of Anti-leishmanial Drugs on Leishmania promastigotes. Iranian Journal of Parasitology, 7(3), 43-47.

Mrityunjaya, M., Pavithra, V., Neelam, R., Janhavi, P., Halami, P. M., \& Ravindra, P. V. (2020). Immune-Boosting, Antioxidant and Anti-inflammatory Food Supplements Targeting Pathogenesis of COVID-19. Frontiers in Immunology, 11.

Nakamura, C. V., Santos, A. O., Vendrametto, M. C., Luize, P. S., Dias Filho, B. P., Cortez, D. A. G., \& Ueda-Nakamura, T. (2006). Atividade antileishmania do extrato hidroalcoólico e de frações obtidas de folhas de Piper regnellii (Miq.) C. DC. var. pallescens (C. DC.) Yunck. Revista Brasileira de Farmacognosia, $16(1), 61-66$

Ostrosky, E. A., Mizumoto, M. K., Lima, M. E. L., Kaneko, T. M., Nishikawa, S. O., \& Freitas, B. R. (2008). Métodos para avaliação da atividade antimicrobiana e determinação da Concentração Mínima Inibitória (CMI) de plantas medicinais. Revista Brasileira de Farmacognosia, 18(2), 301-307.

Othman, L., Sleiman, A., \& Abdel-Massih, R. M. (2019). Antimicrobial Activity of Polyphenols and Alkaloids in Middle Eastern Plants. Frontiers in Microbiology, 10,911.

Pupo, M. T., Gallo, M. B. C., \& Vieira, P. C. (2007). Biologia química: uma estratégia moderna para a pesquisa em produtos naturais. Química Nova, 30(6), $1446-1455$.

Sanches, N. R., Cortez, D. A. G., Schiavini, M. S., Nakamura, C. V., \& Dias Filho, B. P. (2005). An evaluation of antibacterial activities of Psidium guajava (L.). Brazilian Archives of Biology and Technology, 48(3), 429-436.

Silveira, P. F. da, Bandeira, M. A. M., \& Arrais, P. S. D. (2008). Farmacovigilância e reações adversas às plantas medicinais e fitoterápicos: uma realidade. Revista Brasileira de Farmacognosia, 18(4), 618-626.

Teng, T.-S., Ji, A.-L., Ji, X.-Y., \& Li, Y.-Z. (2017). Neutrophils and Immunity: From Bactericidal Action to Being Conquered. Journal of Immunology Research, 2017, 9671604

Vandeputte, D., Kathagen, G., D’hoe, K., Vieira-Silva, S., Valles-Colomer, M., Sabino, J., Wang, J., Tito, R. Y., De Commer, L., Darzi, Y., Vermeire, S., Falony, G., \& Raes, J. (2017). Quantitative microbiome profiling links gut community variation to microbial load. Nature, 551(7681), 507-511.

Vendruscolo, G. S., Rates, S. M. K., \& Mentz, L. A. (2005). Dados químicos e farmacológicos sobre as plantas utilizadas como medicinais pela comunidade do bairro Ponta Grossa, Porto Alegre, Rio Grande do Sul. Revista Brasileira de Farmacognosia, 15(4), 361-372.

Videla, L. A., Barros, S. B., \& Junqueira, V. B. (1990). Lindane-induced liver oxidative stress. Free Radical Biology \& Medicine, 9(2), 169-179.

Wang, Y., Branicky, R., Noë, A., \& Hekimi, S. (2018). Superoxide dismutases: Dual roles in controlling ROS damage and regulating ROS signaling. The Journal of Cell Biology, 217(6), 1915-1928.

Xu, M., Huang, B., Gao, F., Zhai, C., Yang, Y., Li, L., Wang, W., \& Shi, L. (2019). Assesment of Adulterated Traditional Chinese Medicines in China: 20032017. Frontiers in Pharmacology, 10.

Zhang, G., \& Musgrave, C. B. (2007). Comparison of DFT Methods for Molecular Orbital Eigenvalue Calculations. The Journal of Physical Chemistry A, $111(8), 1554-1561$ 